火薬により生成された高速微粒子流を活用した

レーザー誘雷の高効率化

橋本 和久, 武田 和也, 河島 信樹, 島田 義則*，内田 成明*

近畿大学 理工学部（干577-8502 大阪府東大阪市小若江3-4-1)

* (財) レーザー技術総合研究所（５565-0871 大阪府吹田市山田丘2-6）

\title{
Increase of Trigger Efficiency by Using an Artificial Aerosol Flow Produced by Gun Powder in Laser Triggered Lightning Experiment
}

\author{
Kazuhisa HASHIMOTO, Kazuya TAKEDA, Nobuki KAWASHIMA, \\ Yoshinori SHIMADA,* and Shigeaki UCHIDA* \\ School of Science and Engineering, Kinki University, 3-4-1 Kowakae, Higashi-Osaka, Osaka 577-8502 \\ *Institute for Laser Technology, 2-6 Yamadaoka, Suita, Osaka 565-0871
}

(Recieved July 1, 2002)

\begin{abstract}
In order to increase the plasma production efficiency in laser triggered lightning experiments, we propose that a hyper-velocity micro-particle flow produced by a chemical explosion is used along the laser beam path. A preliminary experiment shows the feasibility of the proposed method in the laboratory by using a 100-J, 10-ns $\mathrm{CO}_{2}$ laser.
\end{abstract}

Key Words: Laser, Triggering, Lightning, Micro-particle flow

1.はじめに

落雷は火災や電力設備の破壊，場合によっては人命に 関わる事故を引き起こすこともあり，人々にとっては有 り難くない自然現象である。特に日本においては送電線 等，電力施設への落雷被害が多発しており問題となって いる。このような落雷被害の対策として研究されている のがレーザー誘雷である。これはレーザーを用いて人為 的に落雷を引き起こし, 雷放電を安全なところへ誘導す る技術である。

レーザー誘雷はさらにいくつかの方式に分類される。 その中の 1 つである強電離方式レーザー誘雷は大気中に長 尺のプラズマチャンネルを生成する方法である。この方 式ではしばしば10 $\mu \mathrm{m}$ 程度の比較的波長の長いレーザーが 使用されているが，これは炭酸ガスレーザーのような高 出力のレーザー装置が開発されており, $10 \mu \mathrm{m}$ の光が大気 中を高い透過率で伝搬するためレーザー誘雷への応用が 有利であるためとされている1,2).

炭酸ガスレーザー(波長 $10.6 \mu \mathrm{m})$ を使用した場合，プラ ズマ化のための光強度しきい值は大気分子と比較して, 大気中のエアロゾル(微粒子)の方が低く通常エアロゾルが 先にプラズマ化する，そのため，プラズマチャンネルは 孤立した粒状の強電離プラズマが連なった形で形成され る。このプラズマの間隔が短いほど放電がおこりやすく
なるので，雨や雪などの気象条件により，大気中のエア ロゾル濃度が極端に減少した場合，生成されたプラズマ 間隔が長くなり放電しにくくなる。実際に実験室実験で は，比較的容易にプラズマチャンネルが生成されていた ものが，野外実験では生成が非常に難しくなることが経 験されている3,4).

本研究は人工的にエアロゾル(微粒子) を散布すること により，この問題を解決して安定した誘雷を可能にする ことを目的としている。散布する微粒子は光軸に沿わな いと効果がない。そこで，風等の悪天候中でも微粒子を 光軸上に散布できるようにするために, 火薬を用いて超 高速の微粒子の流れを作り，これをレーザー光の光軸に そって人工的に高速散布し，プラズマチャンネルを効率 よく生成する方法を考案した(Fig. 1)。今回はこの方法を 用いた場合のプラズマチャンネルの様子と，その放電励 起に対する有効性を実証した実験についての報告を行 う.

\section{2. 実験装置}

Fig. 2に実験装置全体の略図を示す。ガラス管内におい て微粒子を噴射し，レーザーによりプラズマチャンネル を生成する．実際にはレーザーと微粒子の噴射方向は同 じにするべきであるが，今回は実験室の都合によりレー 


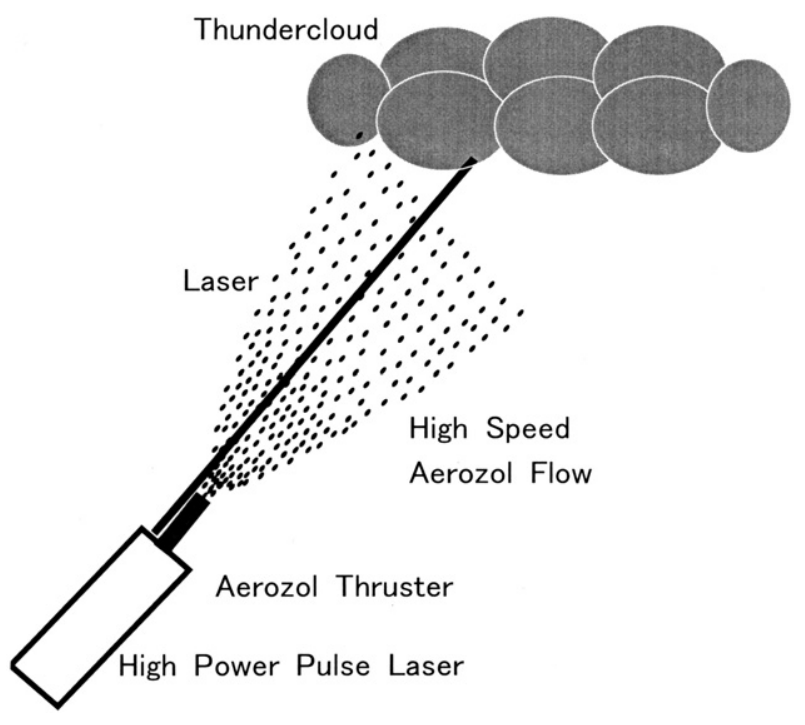

Fig. 1 Use of a high speed aerosol flow to increase the efficiency of the triggering of lightning by a high power laser.

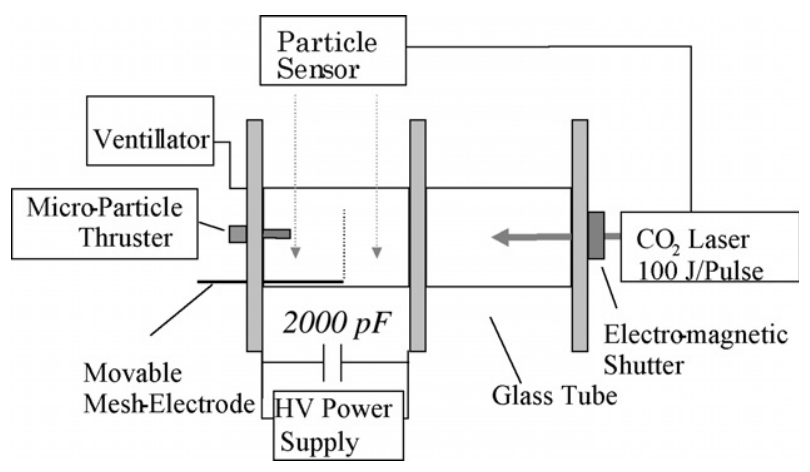

Fig. 2 Experimental configuration.

ザーの進行方向と向かい合う形で配置した。

高速微粒子流を供給するために考案した微粒子噴射装 置の構造をFig. 3に示す。これは密閉したステンレス製の 容器に装填した火薬を点火し, 生成される微粒子を爆压 によりノズルから高速で噴射することにより光軸上に微 粒子の帯(高速微粒子流)を作りだす装置である. 今回の実 験にはパウダー状の黒色火薬を使用した。この薬を使 用したのは入手が比較的容易であることと，燃焼時に約 $50 \%$ が気化して残りが粒子となる5)ので高速微粒子を作る のに適していると判断したからである. 火薬の点火には 電球のフィラメントを利用した。 このフィラメントは 400 $\mathrm{V}$ で充電したコンデンサ $(94 \mu \mathrm{F})$ の電荷をサイリスタでス イッチングして流してやることにより瞬間的に加熱され 火薬に点火する.

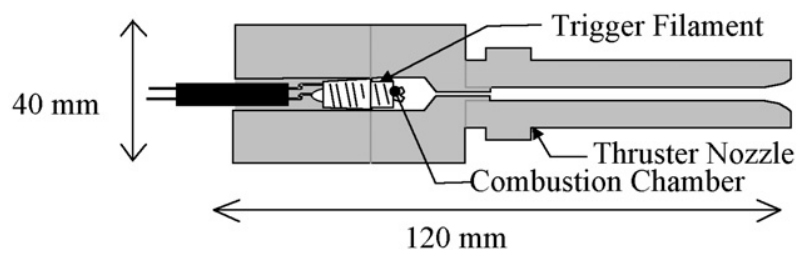

Fig. 3 Artificial aerosol thruster.
レーザーは電子ビーム制御方式のパルス炭酸ガスレー ザーを使用した。発振波長は $10.6 \mu \mathrm{m}$, 発振時間は約 $10 \mathrm{~ns}$ でビーム径は $10 \mathrm{~cm}$ である。パルスあたりのエネルギーは 最大 100 Jであり，ある程度なら調節して発振させること

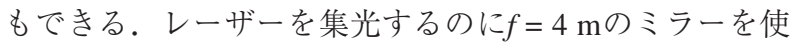
用し，レーザーのトリガには高速微粒子流の通過センサ からの信号を利用した。このセンサはレーザーダイオー ドとフォトトランジスタを使用した光遮断を検知するセ ンサで高速微粒子流が通過すると信号が発生するしくみ である。

電極板にはステンレス製の平板(中心にレーザー入射用 直径 $25.4 \mathrm{~mm}$ 穴付き) と0.5インチメッシュを使用した。コ ンデンサ $(4000 \mathrm{pF}$, 耐圧 $50 \mathrm{kV}) 2$ 本を直列に接続して電極 と並列に挿入し, 高電圧電源 (MAX DC100 kV, $1 \mathrm{~mA}$ ) と $10 \mathrm{M} \Omega$ の充電抵抗によりコンデンサを充電しておくことに より，電極板間に最大 $100 \mathrm{kV}$ の直流電圧を印加することが できるようにした。電極板間にプラズマチャンネルがで き, 放電が励起された場合, コンデンサに充電された電 荷がなくなるため，コンデンサ両端の電圧が降下する。 これはコンデンサの両端の電圧を $1000 \mathrm{M} \Omega$ と $100 \mathrm{k} \Omega$ の抵抗 で分圧することによりオシロスコープで計測した。

\section{3. 実験結果}

\section{1 高速微粒子流の生成}

再現性のよい高速微粒子流をうるために形状やトリ ガーの電源，トリガー電極の配置などの最適化を求める ために多くの時間を要した。Fig. 4に高速微粒子流を撮影 したものを示す。また，微粒子流検出センサーを用いた 微粒子流の到達時間と距離の関係をFig. 5に示す。距離に 比例していないのは, 微粒子流の流れが空気の抵抗で減 速していることを示している。

\section{2 プラズマチャンネルの生成}

高速微粒子流にレーザーを照射することにより，プラ ズマチャンネルを生成する実験を行った。実験に使用し た黒色火薬の量は $0.1 \mathrm{~g}$ と0.2 gである。レーザーは微粒子 噴射装置のノズル先端に集光し，高速微粒子流がノズル 先端より $50 \mathrm{~cm}$ の位置を通過するのをセンサで検知しトリ ガをかけた。このプラズマチャンネルをビデオカメラ $(60$

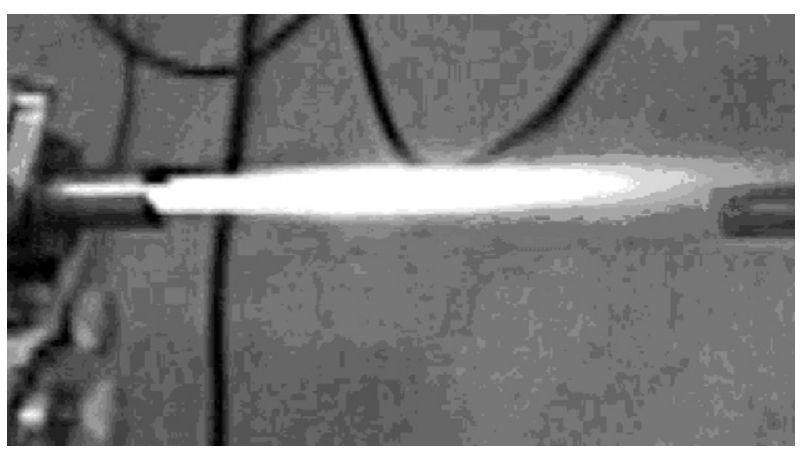

Fig. 4 Time exposure photograph of an artificial aerosol flow. 


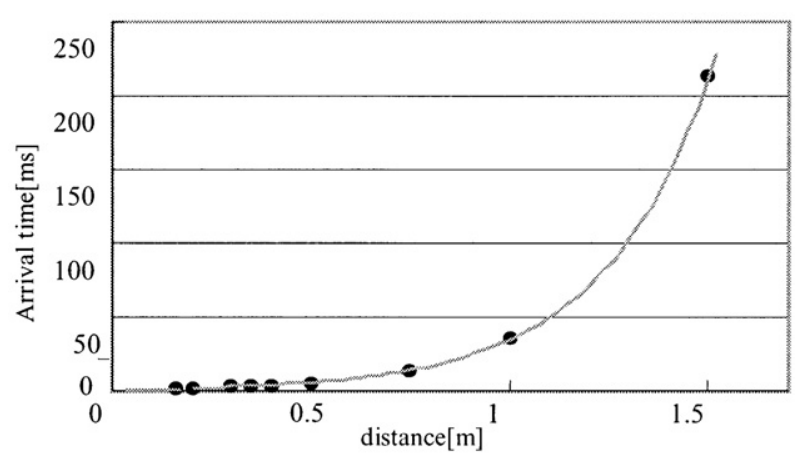

Fig. 5 Arrival time of the artificial aerosol flow with the distance.

fps)で撮影した。また，自然のダスト微粒子のみで生成し たプラズマチャンネルの撮影も行い，高速微粒子流を利 用して生成したプラズマチャンネルとの比較を行った。

Fig. 6に撮影したプラズマチャンネルを示す。この写真 は, 両端の間隔が約 $1 \mathrm{~m}$, レーザー光は, 写真右側から照 射され，焦点距離 $4 \mathrm{~m}$ で写真の左端に焦点を結ぶ.

Fig. 6 (a) は，高速微粒子流がない状態でのレーザーによ るプラズマ生成である。レーザーの焦点付近で点状に明 るくなっているが，自然にあるダスト(エアロゾル)のとこ ろで不連続にプラズマが生成されている. Fig. 6(b) は, 高 速微粒子流を発射してレーザーでプラズマを生成した場 合で，レーザーの光軸にそってプラズマが連続的に生成 されていることが分かる。

\section{3 放電の励起効果}

高速微粒子流を利用して生成したプラズマチャンネル による放電の励起効果の有効性を調べた。電極板間隔20 $\mathrm{cm}$, 印加電圧は $50 \mathrm{kV}$ で実験を行った. 高速微粒子流は黒 色火薬 $0.1 \mathrm{~g}$ を使用して生成した。レーザーのエネルギーと

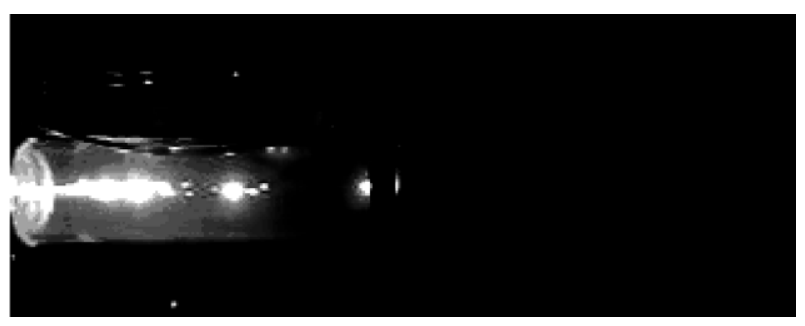

(a)

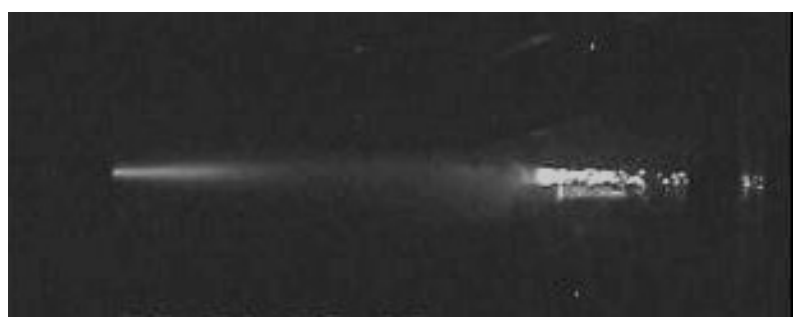

(b)

Fig. 6 Plasma channel produced by the laser (laser energy/ shot $=18 \mathrm{~J}$ ). (a) without the artificial aerosol flow and (b) with the artificial aerosol flow (gun powder: $0.1 \mathrm{~g})$.
トリガのタイミングを変えて行き，それぞれの条件でプ ラズマチャンネルが放電を励起できるかどうかを調べ た.レーザーのトリガのタイミングはノズル先端に設置 した高速微粒子流通過センサの反応時から任意の遅延時 間を設定することにより変化させた．放電の有無の確認 はビデオカメラによる撮影と, 電極板間の電圧の計測に より行った。

実験結果を Fig. 7に示す。横軸にレーザーのエネル ギー, 縦軸にレーザーのトリガー・タイミングで高速微 粒子流のノズル先端通過時からの遅延時間をとってい る。自然に存在しているダスト微粒子だけを利用した場 合を遅延時間 $0 \mathrm{~s}$ とした．プラズマチャンネルが放電を励 起した場合を○印，励起しなかった場合には×印で表し ている。また，コンデンサにためた電荷が完全に放電し きらずに，一部だけ放電するという現象が見られたので 2 $\mathrm{kV}$ 以上放電した事象については $\Delta$ 印で表した。このグラ フから分かるように高速微粒子流を使わない場合 (Delay time $=0)$, $30 \mathrm{~J}$ 以上でないと放電しない. 高速微粒子流 を用いると, とくに遅延時間 $2 \sim 3 \mathrm{~ms}$ において完全な放電 が20Jくらいまで励起されており，また部分的な放電は， もっとずっと低いエネルギーでも励起されている。この ことから, レーザーのみの場合と比べ，高速微粒子流を 用いると, 安定して放電を励起することができるだけで なく，より低い電圧でも放電を励起できるということが 確認できた。

\section{4. 検 討}

自然に存在しているダスト微粒子だけを利用した場 合，十分放電を励起できると思われる条件下でも放電の 励起に失敗することが多い。これはダスト微粒子の分布 が安定しておらず，プラズマチャンネルが途中で大きく とぎれるなどしたためであると考えられる。それに対し て高速微粒子流を利用した場合は, 常に安定した量の微 粒子を供給することができるので, 安定して放電を励起 することができた。また，高速微粒子流を利用すること により，より低い電圧で放電を励起できることも確認で きた。これはFig. 6 に示したように自然に存在している夕゙ スト微粒子だけを利用した場合と比較して，プラズマ間

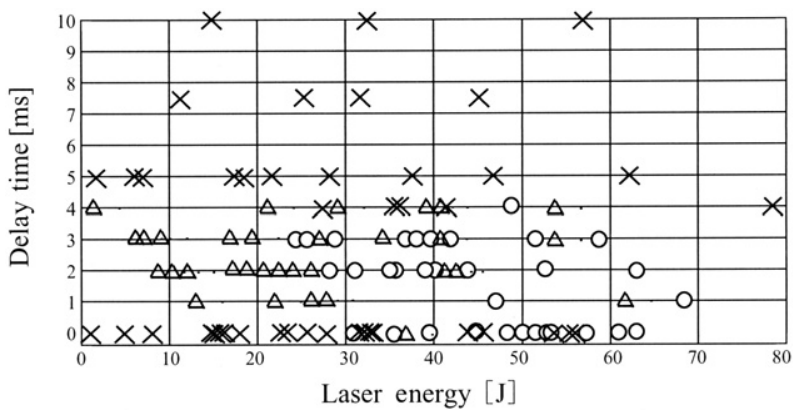

Fig. 7 Effect of the artificial aerosol to the discharge by the laser. The delay time 0 means without any artificial aerosol. Here, $[\bigcirc]$ shows that a clear discharge (complete discharge of the capacitor) is excited, $[\triangle]$ a partial discharge and $[\times]$ no discharge is excited. 
隔の短いプラズマチャンネルを作ることができたためで あると考えられる。プラズマ間隔が短い方が放電を励起 する効果は高くなる ${ }^{3)}$.

なお，この実験では高速微粒子流を利用した場合でも 遅延時間 $5 \mathrm{~ms}$ 以上ではほとんど放電を励起することができ なかった。これには次のような理由が考えられる。今回 の実験ではレーザーは高速微粒子流の先端より入射させ た。このためプラズマチャンネルは高速微粒子流の先頭 より生成されてゆく、レーザー照射のトリガタイミング を遅らせた場合, 高速微粒子流はその時間分先に進んで いるのでプラズマチャンネルのできる位置も変わってく る.このため, 遅延時間が長い場合は高速微粒子流の先 端が電極板間の領域を通り抜け，電極板間でプラズマ チャンネルがあまりできなくなってしまったのである。

\section{5. まとめ}

今回の実験では人工的に生成した高速微粒子流を利用 することにより，安定して放電を励起することのできる プラズマチャンネルを作ることができることを示し，こ の方式のレーザー誘雷における放電励起に対する有効性
を実証した。またこのプラズマチャンネルは自然に存在 しているダスト微粒子だけを利用した場合のプラズマ チャンネルと比較して，より低い電圧で放電を励起する ことができることも明らかにした。これらの結果より強 電離方式のレーザー誘雷に高速微粒子流を利用すること は非常に有効であるといえる。今後，さらにどのように レーザーと高速微粒子流を組み合わすのが有効なのかを 火薬の質・量や噴射ノズルの形状，レーザーのタイミン グや光学系の設定等の観点から検討を行い，この方法に よる長距離放電実験での検証を行っていく予定である.

\section{参考文献}

1) 山中 龍彦：レーザー研究 5 (1996) 533.

2) 山中 龍彦, 内田 成明: 原子力と先端技術 [III] ((社) 日本原 子力産業会議 日本原子力シスステム研究懇話会, 1996) p. 73.

3) 島田義則, 内田成明, 安田裕彦, 本越伸二, 山中千代衛, 王 道洪, 綿田 恭之, 河崎 善一郎, 山中 龍彦, 石窪 雄二, 足立 幹雄：レーザー研究 5 (1996) 572.

4) 安田裕彦, 内田成明, 島田 義則, 本越伸二, 椿本 孝治, 山 中千代衛, 藤田 尚徳, 井澤靖和, 山中 龍彦, 河崎 善一郎, 石窪 雄二，足立 幹雄：レーザー研究 5 (1996) 582

5) 吉田忠雄, 田村昌光：エネルギー物質の科学（朝倉書店, 1996) p. 124. 